\title{
THE ACCESSIBILITY OF EUROPEAN REGIONS AND AIRPORT NETWORK
}

Renato Redondi ${ }^{13}$

University of Bergamo, Italy

Paolo Malighetti ${ }^{14}$

University of Bergamo, Italy

Stefano Paleari ${ }^{15}$

University of Bergamo, Italy

\section{ABSTRACT}

The objective of this work is to evaluate the accessibility of European municipalities by air transport. We focus on travels that typically require the use of air transport by computing the quickest paths between any pair of municipalities separated by more than $500 \mathrm{~km}$. The total travel time includes three components: i) travel by car or High Speed Train to reach the origin airport, ii) travel by air from the origin airport to the destination airport, including waiting times when no direct flight is available and iii) travel by car or High Speed Train from the destination airport to the municipality of destination. For each territorial unit, we calculate the population-weighted average travel time to reach any other municipality in Europe.

${ }^{13}$ Contact Author: Renato Redondi, University of Bergamo (Italy), renato.redondi@unibg.it Associate professor at the University of Brescia and board member of SACBO, the company which manages the Bergamo Orio al Serio Airport. His main research interests are the study of the connectivity and the development of the airport network and the study of the fares offered by traditional and low-cost carriers.

14 Paolo Malighetti, University of Bergamo (Italy), paolo.malighetti@unibg.it

Associate professor at the University of Bergamo. His main research interests are the study of the airport network and the fares offered by traditional and low-cost carriers. He is Academic Coordinator of ICCSAI and is responsible for its annual report on the competitiveness of air transport in Europe.

${ }^{15}$ Stefano Paleari, University of Bergamo (Italy), stefano.paleari@unibg.it

Rector of the University of Bergamo. He has been a member of the Council and General Secretary of the CRUI (the Conference of Italian University Rectors) since April 2011. From April 2013, he has been a member of the Board of the European University Association. He is Scientific Director of ICCSAI. 
This statistic identifies which European regions are "remote" due to difficulties accessing the nearest airport or a limited offer of flights. Finally, we propose a general framework to evaluate policy options for improving the accessibility of remote regions.

Keywords: Airport Network, Accessibility, Remote regions, Policy options, Shortest Path, European market . 


\section{INTRODUCTION}

Wegener et al. (2001) defined accessibility in terms of indicators that "describe the location of an area with respect to opportunities, activities or assets existing in other areas and in the area itself, where 'area' may be a region, a city or a corridor". Evaluating the accessibility offered to citizens has always been an important issue for policy makers and regional governments, so a large body of literature has studied the relationship between accessibility and regional development (for example, Spiekermann and Wegener, 2006, Vickerman, 1999).

The objective of this work is to study accessibility in Western Europe, taking into account both air and ground transportation. We focus on travels that typically require the use of air transport by computing the quickest paths between any pair of municipalities separated by more than $500 \mathrm{~km}$.

Air transportation accounts for a significant portion of travel times between most pairs of municipalities. Burghouwt and Veldhuis (2006) employed air-side accessibility measures to evaluate the connectivity of European airports involved in the transatlantic market. Paleari et al. (2010) compared air-side accessibilities for Europe, US and China. Shaw (1993) and Shaw and Ivy (1994) studied the accessibility of the hub-and-spoke structure to US airline passengers. When computing travel times by air, this work employs a definition similar to that of Paleari et al. (2010): the total air travel time includes both flight times and waiting times spent in intermediate airports when no direct flight is available.

The contributions of this paper with respect to previous studies are related to three aspects. Firstly, when computing the accessibility index the paper employs an origin-destination approach, jointly considering the effects land-side accessibility to airports and air-side accessibility offered by airports. The latter also considers waiting times in intermediate airports when direct flights are not available, calculated on published flight scheduling.

Secondly, while previous studies on European intermodal accessibility have considered only NUTS23 regions (Lutter et al., 1992; Chatelus and Ulied, 1995; Wegener et al., 2001; Copus et al., 2002), this paper computes travel times in a much more detailed network with 76,498 distinct municipalities. It allows considering for each municipality in Europe, the effective infrastructures employed, including the choice of the most convenient airports, depending on the specific municipalities of origin and destination, and the ground access to those airports.

Thirdly, from a policymaker perspective this paper proposes an innovative framework for evaluating the priority to improve accessibility of remote regions. That could be obtained, for example, by increasing air services offered by airports serving remote regions, that is the standard approach 
adopted by policymakers when setting Public Service Obligations - PSO. However, the paper also identifies the cases in which a more effective approach would be to invest in land-side infrastructures to allow travelers to quickly reach major airports that are farther away from remote regions but with better developed air networks.

The paper is organized as follows. The next section describes the methodology and dataset employed. Section 3 describes our empirical results on the overall accessibility of cities. Section 4 focuses on remote territories and proposes a general framework for improving accessibility. Section 5 concludes.

\section{METHODOLOGY AND DATA}

Table 1 shows the twenty Western European countries and territories covered by our analysis. Our dataset includes 76,498 different municipalities, with a total population of more than 378 million and an average population per municipality of about 5,000.

This paper computes travel times for journeys between each pair of municipalities in the sample, including ground and air travel. The overall travel time to connect municipalities $i$ and $j$, denoted $t_{i, j}$, is separated into three components:

1) $t_{i, 0}$ : travel time by car or High Speed Train (HST) from the origin municipality $\left(M_{i}\right)$ to the origin airport $\left(A_{0}\right)$. This is a much more precise approach than those employed by previous studies since it allows considering the specific infrastructures necessary to access the airports, including the presence of freeways, speed limits and HST services. The latter includes all HST services coordinated between the train operators and the airlines.

2) $t_{0, d}$ : travel time by air from the origin airport $\left(A_{0}\right)$ to the destination airport $\left(A_{d}\right)$. If a direct flight exists $t_{0, d}$ only includes the flight time. If no direct flight is available between the origin and the destination airports, this component includes both flying times and waiting times in intermediate airports ${ }^{16}$. For indirect connections, we assume a minimum interconnecting period of 45 min for all intermediate airports. To guarantee the feasibility of connections we consider scheduled flights operating on a specific and typical day in autumn: Wednesday, 12 October 2011. Information on scheduled flights is collected from the OAG (Official Airline Guide) dataset.

To compute the minimum travel time $t_{0, d}$ by air, we apply the methodology introduced by Malighetti et at. (2008).

${ }^{16}$ Some passengers may prefer to make one-stop trips even if direct flights are available, when lower fares compensate the costs of the extra time. However, since we aim to evaluate remoteness, we build a time-based index. For this reason, information on offered fares is not considered in this analysis. 
3) $t_{d, j}$ : travel time by car or HST from the destination airport $\left(A_{d}\right)$ to the destination municipality $\left(M_{j}\right)$.

Table 1. Countries, municipalities and populations covered by the analysis. Year 2011.

\begin{tabular}{|c|c|c|c|c|}
\hline Country & $\begin{array}{l}\text { No. of airports } \\
\text { considered }\end{array}$ & No. of municipalities & Population & $\begin{array}{l}\text { Population } \\
\text { municipality }\end{array}$ \\
\hline Austria & 6 & 2,259 & $8,208,012$ & 3,633 \\
\hline Belgium & 5 & 580 & $10,801,107$ & 18,623 \\
\hline Denmark & 6 & 96 & $5,399,255$ & 56,242 \\
\hline England & 47 & 2,109 & $44,021,561$ & 20,873 \\
\hline Finland & 12 & 414 & $5,295,918$ & 12,792 \\
\hline France & 45 & 36,040 & $60,884,686$ & 1,689 \\
\hline Germany & 39 & 12,187 & $81,551,275$ & 6,692 \\
\hline Ireland & 3 & 78 & $2,327,507$ & 29,840 \\
\hline Italy & 38 & 8,101 & $60,045,068$ & 7,412 \\
\hline Luxemburg & 1 & 36 & 314,046 & 8,724 \\
\hline Netherlands & 5 & 491 & $15,761,607$ & 32,101 \\
\hline Northern Ireland & 2 & 16 & 840,290 & 52,518 \\
\hline Norway & 30 & 423 & $4,440,441$ & 10,497 \\
\hline Portugal & 3 & 283 & $9,934,918$ & 35,106 \\
\hline Scotland & 8 & 583 & $4,590,490$ & 7,874 \\
\hline Slovenia & 1 & 200 & $1,935,248$ & 9,676 \\
\hline Spain & 39 & 7,983 & $45,076,146$ & 5,647 \\
\hline Sweden & 36 & 1,886 & $7,520,741$ & 3,988 \\
\hline Switzerland & 5 & 2,524 & $7,494,142$ & 2,969 \\
\hline Wales & 1 & 209 & $2,320,880$ & 11,105 \\
\hline All territories & & 76,498 & $378,763,338$ & 4,951 \\
\hline
\end{tabular}

Before this analysis can begin, we need to link each municipality with the airports most likely to be employed by its population. We consider the two nearest airports for each municipality, in terms of travel times in 2011. We also include any other airports offering more than 50 routes (again, in 2011) within $200 \mathrm{~km}$ of the municipality.

We do not consider travel times between pairs of municipalities whose distance is less than $500 \mathrm{~km}$, since air travel is probably not necessary to complete the journey. 
Among all possible combinations of origin airport and destination airport for a given pair $(i, j)$, we find those which give the minimum travel time $t_{i, j}=t_{i, o}+t_{o, d}+t_{d, j}$.

In general, there could be different airport pairs to allow travelling from municipality $\mathrm{i}$ to $\mathrm{j}$. That is the case of municipalities located in the catchment areas of different airports. An innovative feature of this approach is that it selects the alternative path with the lowest travel time $t_{i, j}$. For example, if a passenger located in the London area wants to reach a destination in the Milan area, the algorithm selects the best departure and arrival airport in order to reduce overall travel time $t_{i, j}$. The optimal solution depends on the specific municipalities of origin and destination.

In general, the most well-connected municipalities are close to airports linked by a direct flight. In contrast, remote municipalities often involve long travel times by car to reach the origin airport and/or an indirect flight to the destination airport.

The accessibility index for a municipality, denoted $t_{i}$, is defined as the population-weighted average travel time to all other municipalities:

$$
\mathrm{t}_{\mathrm{i}}=\frac{\sum_{\mathrm{j}=1}^{\mathrm{n}_{\mathrm{i}}} \mathrm{p}_{\mathrm{j}} \cdot \mathrm{t}_{\mathrm{ij}}}{\sum_{\mathrm{j}=1}^{\mathrm{n}_{\mathrm{i}}} \mathrm{p}_{\mathrm{j}}}
$$

Here $n_{i}$ is the number of municipalities farther than $500 \mathrm{~km}$ from municipality $i$ and $p_{j}$ is the population of municipality $\mathrm{j}$. By weighting for the population of municipalities we consider the different attractiveness of the connections. Since on average remote municipalities are less populated, travel times to reach them are also underweighted. The difference between our approach and the gravity approach is that we do not consider in the weighting system the "as the crow flies" distance between origin and destination municipalities. Our analysis is restricted to Europe and only when distances between origin and destination are higher than $500 \mathrm{~km}$. Paleari et al. (2010) show that $80 \%$ of direct flights in Europe have a distance between 1.000 and $2.500 \mathrm{~km}$. So, for European connections the population-weighted index is not significantly different from the gravity approach. 


\section{EMPIRICAL RESULTS}

Table 2 reports our statistics on accessibility, grouping the municipalities by country or territory. The average accessibility index of a country depends on its geographical position with respect to the other countries. England is the most well-connected country in Western Europe, with the smallest weighted average travel time $t$. It is noteworthy that in terms of travel times, England is more accessible than countries that are geographically central such as Austria, Germany and Switzerland. As expected, the least connected countries are Finland, Norway and Sweden. Norway has the greatest variation in the weighted average travel times of individual municipalities, with a standard deviation of 74.8 minutes.

Figure 1 shows the distribution of municipalities by accessibility index t. Almost $90 \%$ have a weighted average travel time less than 400 minutes. Given than the overall average is about 300 minutes (Table 2), the vast majority of municipalities have accessibility indexes not exceeding the average by more than $30-35 \%$. However, the least connected municipalities have accessibility indexes exceeding 600 minutes, almost twice the average.

Figure 1. Distribution of territories by accessibility index.

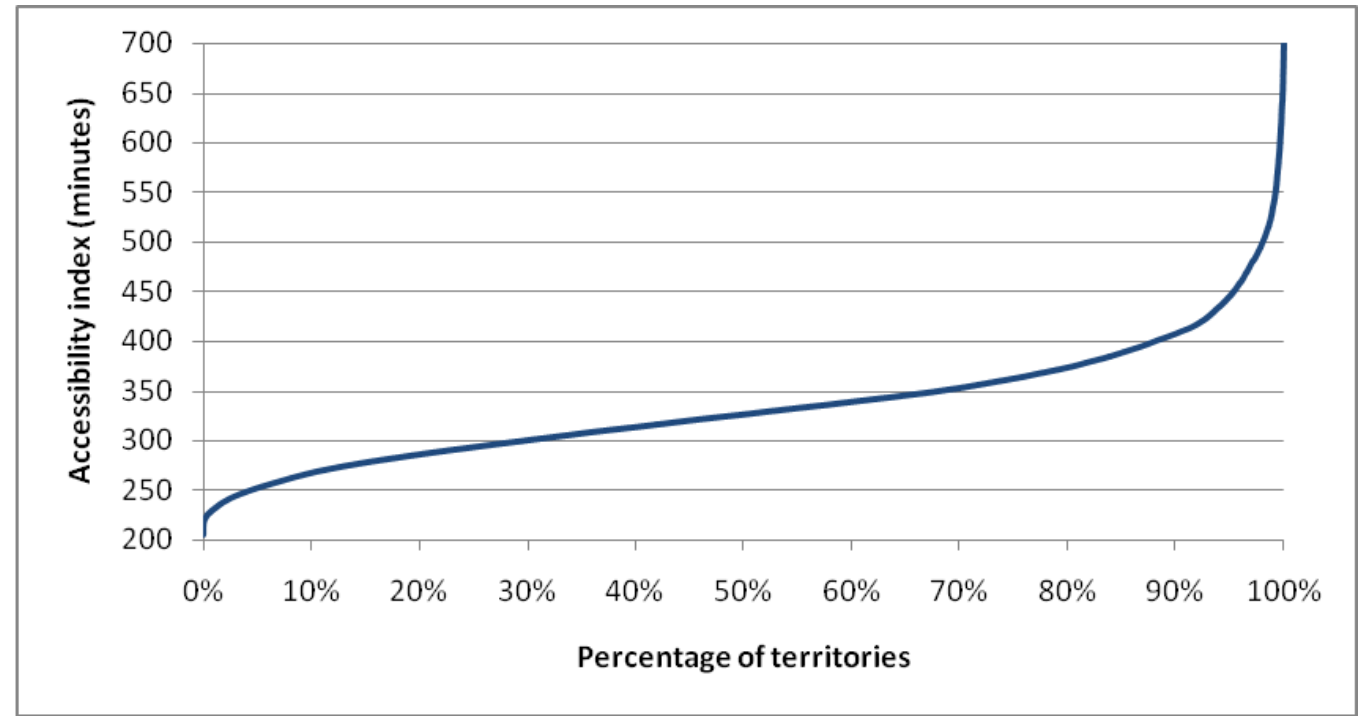


Table 2. Accessibility statistics by country (in minutes).

\begin{tabular}{|c|c|c|c|c|c|}
\hline Country & Weighted average & Median & Minimum & Maximum & Std. Dev \\
\hline Austria & 287.5 & 307.8 & 227.6 & 406.7 & 27.0 \\
\hline Belgium & 309.0 & 296.5 & 279.5 & 384.0 & 20.2 \\
\hline Denmark & 286.1 & 290.9 & 221.9 & 456.6 & 46.4 \\
\hline England & 266.1 & 260.6 & 216.3 & 595.3 & 35.7 \\
\hline Finland & 402.0 & 453.4 & 297.4 & 634.7 & 69.2 \\
\hline France & 310.5 & 334.8 & 220.7 & 706.5 & 60.7 \\
\hline Germany & 306.0 & 298.9 & 217.7 & 548.2 & 35.8 \\
\hline Ireland & 293.1 & 309.3 & 231.8 & 461.8 & 67.8 \\
\hline Italy & 303.8 & 309.1 & 210.4 & 681.0 & 55.4 \\
\hline Luxemburg & 369.2 & 297.8 & 322.3 & 394.5 & 14.4 \\
\hline Netherlands & 312.1 & 309.7 & 276.1 & 416.1 & 19.2 \\
\hline North. Ireland & 297.9 & 295.5 & 276.7 & 341.9 & 17.6 \\
\hline Norway & 377.9 & 417.7 & 271.9 & 691.2 & 74.8 \\
\hline Portugal & 322.2 & 342.0 & 267.1 & 564.0 & 41.9 \\
\hline Scotland & 293.4 & 293.0 & 229.9 & 634.4 & 54.1 \\
\hline Slovenia & 337.2 & 348.3 & 295.9 & 459.4 & 25.9 \\
\hline Spain & 305.2 & 339.3 & 204.7 & 674.0 & 60.2 \\
\hline Sweden & 370.7 & 409.7 & 274.7 & 640.3 & 71.4 \\
\hline Switzerland & 271.8 & 282.5 & 231.7 & 387.0 & 23.4 \\
\hline Wales & 313.9 & 311.3 & 243.7 & 504.8 & 42.3 \\
\hline All territories & 305.4 & 324.5 & 204.7 & 706.5 & 60.8 \\
\hline
\end{tabular}


Figure 2. Accessibility index by municipality.

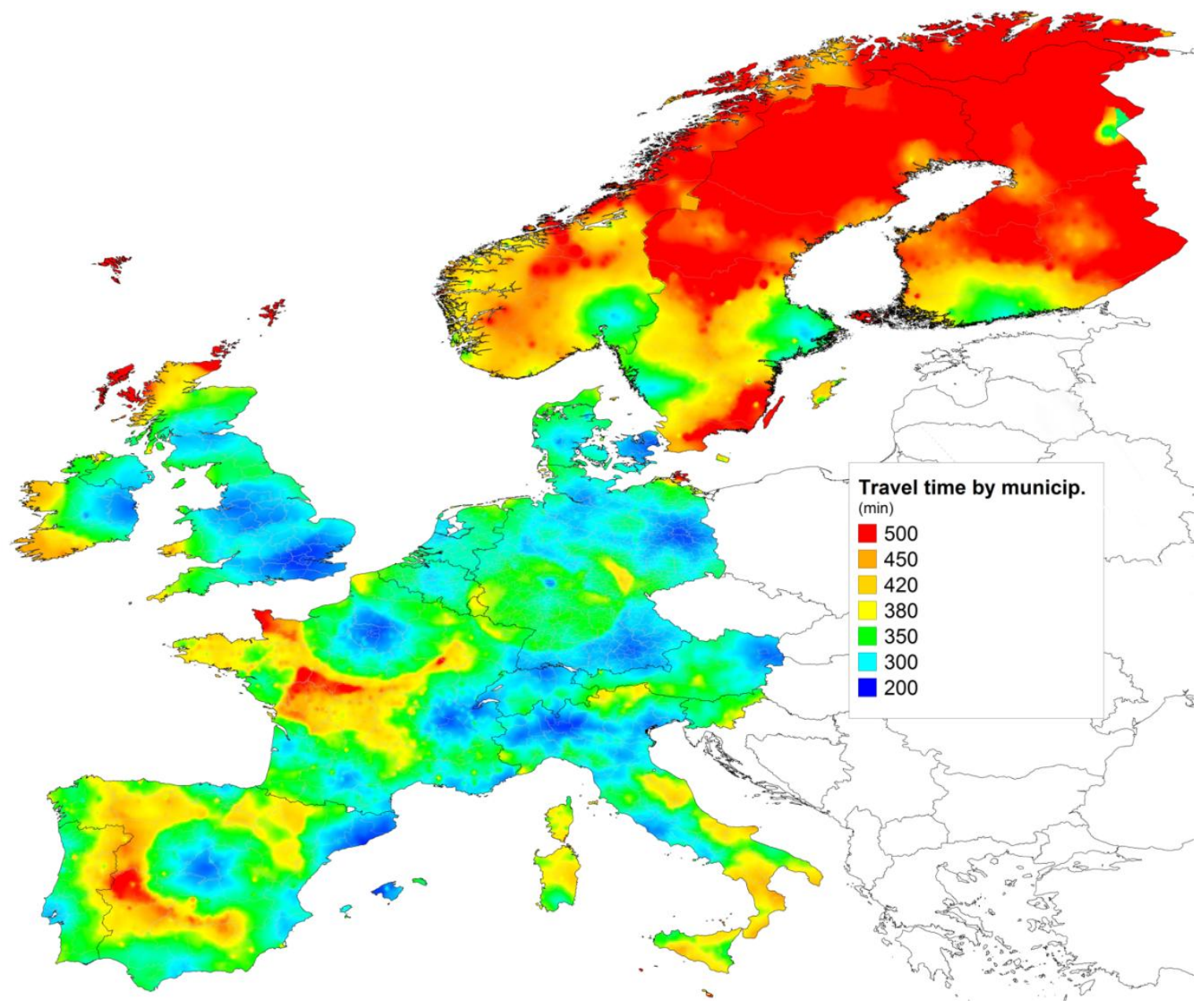

Figure 2 shows the geographic distribution of the accessibility index. It shows that even municipalities located near the geographic center of Europe may have low accessibility. This phenomenon is more accentuated in France, where small airports tend to have just a few European connections. In Spain, low accessibility affects cities close to Portugal and those located midway between the seaside and Madrid. 
Table 3. Identification of remote territories.

\begin{tabular}{llllll}
\hline & \multicolumn{5}{c}{ Population in Remote municipality } \\
\hline Percentile & $90.0 \%$ & $92.5 \%$ & $95.0 \%$ & $97.5 \%$ & $99.0 \%$ \\
\hline Travel time limit & 408.0 & 421.1 & 445.9 & 487.9 & 536.5 \\
\hline Denmark & 2,089 & 1,993 & 1,993 & - & - \\
England & 40,022 & 5,999 & 2,275 & 2,275 & 2,275 \\
Finland & $2,386,398$ & $2,218,248$ & $1,602,466$ & 876,529 & 178,535 \\
France & $3,908,435$ & $3,132,755$ & $1,857,975$ & 992,279 & 320,457 \\
Germany & 211,778 & 82,304 & 60,890 & 55,650 & 8,903 \\
Ireland & 316,869 & 290,308 & 82,558 & - & - \\
Italy & $2,290,288$ & $1,323,297$ & 122,309 & 15,498 & 6,170 \\
Norway & $1,046,552$ & 853,572 & 584,225 & 239,851 & 125,144 \\
Portugal & 471,728 & 291,870 & 66,058 & 29,721 & 29,721 \\
Scotland & 56,600 & 49,630 & 44,300 & 42,420 & 41,800 \\
Slovenia & 16,883 & 16,883 & 9,334 & - & - \\
Spain & $2,422,075$ & $1,616,118$ & 781,126 & 378,091 & 91,381 \\
Sweden & $2,396,662$ & $2,028,237$ & $1,133,261$ & 575,144 & 77,271 \\
Wales & 64,831 & 49,737 & 4,515 & 4,515 & - \\
\hline Number of & 7,634 & 5,725 & 3,817 & 1,909 & 764 \\
territories & $15,631,210$ & $11,960,951$ & $6,353,285$ & $3,211,973$ & 881,657 \\
\hline Population & & & & &
\end{tabular}

Table 3 aims to identify the remote territories. In particular, it shows the total populations of the least connected areas in each country, counting all municipalities with travel times above the $90 \%$, $92.5 \%, 95 \%, 97.5 \%$ and $99 \%$ percentiles computed for the entire sample.

Interestingly, Austria, Belgium, Luxemburg, Northern Ireland, Netherland and Switzerland do not have any municipality with an accessibility index above the $90 \%$ percentile. The countries with the largest populations in remote municipalities are the three Scandinavian countries (Sweden, Norway, and Finland) together with France, Spain, and Italy.

The remainder of our analysis deals with those municipalities whose accessibility indexes are above the 95th percentile, meaning that their travel times are greater than 445.9 minutes. Henceforth, the term "remote territory" refers to one of these cities. The number of remote territories is 3,817 , and their total population is more than 6 million. Following this definition, Austria, Belgium, Luxemburg, Netherland, Northern Ireland and Switzerland do not have any remote territories. In fact, from table 2 one would observe that their maximum accessibility indexes are lower than the limit of 445.9 minutes. 


\section{REMOTE TERRITORIES AND POLICY IMPLICATIONS}

Table 4 shows statistics on travel times for remote territories. Interestingly, France comes first in terms of the total population in remote territories, followed by Finland and Sweden. All three countries have more than one million people living in their remote territories.

Spain has about 780,000 people living in remote territories, and Norway has about 580,000. Table 4 also decomposes the travel times from remote territories into three components: i) travel to the origin airport, ii) travel by air, and iii) travel from the destination airport to the destination territory. (These components were defined in Section 2.)

Table 4. Statistics on travel times for remote territories (travel times in minutes).

\begin{tabular}{llllllll}
\hline & $\begin{array}{l}\text { No. of remote } \\
\text { territories }\end{array}$ & Population & $\begin{array}{l}\text { Average } \\
\text { Access. } \\
\text { Index }\end{array}$ & $\begin{array}{l}\text { Travel } \\
\text { to origin } \\
\text { airport }\end{array}$ & $\begin{array}{l}\text { Travel } \\
\text { by air }\end{array}$ & $\begin{array}{l}\text { Travel } \\
\text { from dest. } \\
\text { airport }\end{array}$ & $\begin{array}{l}\text { Sev. } \\
\text { Denmark }\end{array}$ \\
England & 1 & 1,993 & 456.6 & $28.9 \%$ & $56.7 \%$ & $14.4 \%$ & - \\
Finland & 222 & 2,275 & 595.3 & $39.5 \%$ & $49.2 \%$ & $11.4 \%$ & - \\
France & 2,145 & $1,602,466$ & 495.2 & $16.0 \%$ & $70.8 \%$ & $13.2 \%$ & 37.5 \\
Germany & 41 & 60,890 & 519.5 & $54.6 \%$ & $33.6 \%$ & $11.8 \%$ & 27.9 \\
Ireland & 7 & 82,558 & 449.4 & $27.8 \%$ & $58.0 \%$ & $14.2 \%$ & 5.1 \\
Italy & 49 & 122,309 & 470.4 & $33.9 \%$ & $52.0 \%$ & $14.1 \%$ & 34.9 \\
Norway & 288 & 584,225 & 497.6 & $21.0 \%$ & $67.4 \%$ & $11.6 \%$ & 70.8 \\
Portugal & 6 & 66,058 & 504.1 & $41.7 \%$ & $45.4 \%$ & $12.9 \%$ & 41.9 \\
Scotland & 13 & 44,300 & 588.8 & $11.2 \%$ & $78.4 \%$ & $10.4 \%$ & 63.2 \\
Slovenia & 1 & 9,334 & 459.4 & $35.4 \%$ & $50.4 \%$ & $14.2 \%$ & - \\
Spain & 414 & 781,126 & 493.4 & $23.9 \%$ & $62.9 \%$ & $13.2 \%$ & 36.5 \\
Sweden & 628 & $1,133,261$ & 490.5 & $11.1 \%$ & $75.3 \%$ & $13.6 \%$ & 34.7 \\
Wales & 1 & 4,515 & 504.8 & $41.1 \%$ & $44.7 \%$ & $14.2 \%$ & - \\
\hline All territories & 3817 & $6,353,285$ & 517.3 & $22.6 \%$ & $64.5 \%$ & $12.9 \%$ & 49.4 \\
\hline
\end{tabular}

Long air travel times imply that the origin airports do not have direct flights to many destination airports, so travelers accumulate waiting time in intermediate airports. Long travel times to or from an airport indicate problems of geographical accessibility.

The case of France is of particular interest. In this country, there are two areas with municipalities classified as remote (see figure 2). The first includes territories in the lower Normandy region, 
closer to the English Channel. That does not come as a surprise since that area is relatively isolated and not served by high speed train - HST.

The second includes more central municipalities located in the Centre and Pays de la Loire regions, despite being served by HST. Our approach already considered all scheduled HST offered in coordination with Air France flights. However, even if travel time by HST to Paris Charles de Gaulle is relatively short, on average travelers have to wait here more than 110 minutes before taking a flight to the European destination considered, employing a minimum connection time of 45 minutes. Furthermore, the French remote municipalities identified in this study are distant from the nearest HST stations by more than 90 minutes by road. So, after considering all those components, average time to take a European flight from Paris Charles de Gaulle can easily be higher than 250-300 minutes, against an average of 117 minutes of land-side accessibility for remote regions (see table 4). So, HST in France does not improve the overall accessibility index of these municipalities.

\subsection{Statistical Properties Of Remote Regions}

For the six countries with the largest populations in remote territories, Figure 3 plots the percentage of travel time to the origin airport against the percentage of air travel time.

For Sweden and Finland, the main factor contributing to long travel times is the quality of connections offered from origin airports. In Spain and France, on the other hand, the main problem is the excessive distance between remote territories and the most suitable origin airports.

The division into ground and air travel offers insight into the types of policy remedies that would be effective. When a country's remote territories require long air travel times, their accessibility could be improved by increasing the origin airports' offer of direct flights, especially to the major European airports (Redondi et al., 2010). However, this is not always the most effective policy. For example, it could be that an airport serving several remote territories is very small, with a very limited capacity. In this case, the bottleneck could be overcome by improving land-side accessibility to larger airports. 
Figure 3. Proportions of travel times in remote regions due to ground travel and air travel .

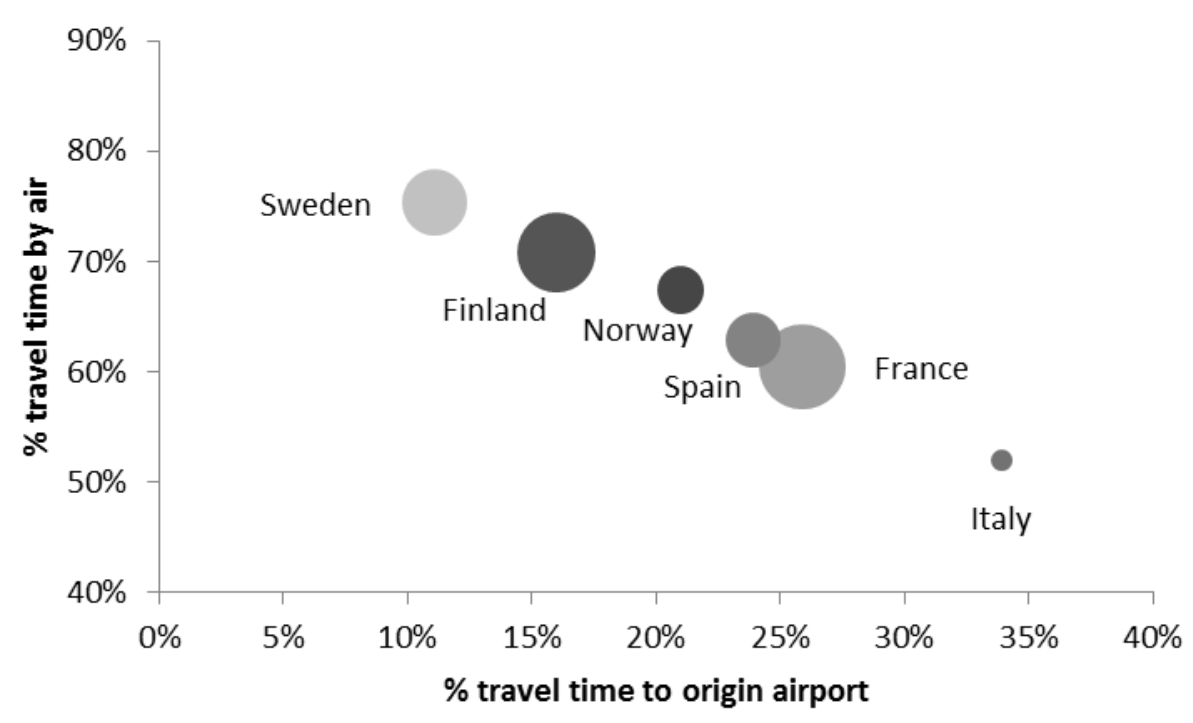

When the main problem faced by remote territories is high travel times to reach origin airports, the most evident solution would be improving land-side infrastructure. For example, a government could improve existing roads or build new highways from remote regions to serve major airports. Another solution would be to create new airports to serve the remote regions. However, it could also be that the airports closest to remote territories are not often employed by the population, due to a low number of offered flights and destinations. If this is the case, travelers would often drive to a farther airport with better connectivity. Thus, land travel times could also be reduced by increasing the connectivity of nearby airports.

In order to better differentiate the policies required to improve the accessibility of remote regions, Table 5 provides detailed information regarding the land-side accessibility of origin airports in each country. The first column is the total population of remote territories in that country, and the second column is the average number of origin airports linked to each remote territory (see Section 2). From the methodology section, the minimum number of airports linked to each territory is two. The second and third columns describe the propensity of the population to use just one of the linked airports. The concentration is the value of the Herfindahl-Hirschman Index - HHI. When this index equals 10,000 , it means that passengers from remote municipalities have no choice but to employ only one origin airport to reach their destinations.

The lower the index, the higher the number of alternative departure airports that are employed to reach destinations in quickest paths. 
The fourth column reports the percentage of the population that finds it quicker to travel to the closest airport, regardless of destination. Table 5 also reports the average travel time to reach the closest airport, and the average travel time to reach the linked airport or airports that are located farther away.

In order to compare the connectivity of the closest airport with the connectivity of other potential origin airports, we define the following index:

$$
\mathrm{C}_{\mathrm{d}}=(1-\% \mathrm{Pop}) \times \Delta \mathrm{TT}
$$

Here \%Pop is the percentage of the population that finds it quicker to employ the closest airport, reported in the $4^{\text {th }}$ column of Table 5. $\Delta T \mathrm{~T}$ is the difference between the average travel time required to reach the closest airport and the average travel time to other airports, reported in the $5^{\text {th }}$ and $6^{\text {th }}$ columns of Table 5 respectively.

We name $C_{d}$ the "connectivity deficit" of the closest airport with respect to the other airports that serve the area. The rationale of $C_{d}$ is to measure the potential advantage of policies to improve the network quality of the closest alternative. It measures the average time lost by a person living in one of the remote territories who has to use an airport with better connections farther away than the closest alternative. So, if network quality of the closest airport improved, travelers would save $\mathrm{C}_{\mathrm{d}}$ in terms of access time.

Among countries with a large population in remote territories, the connectivity deficit is highest for Italy, at 23.7 minutes. The value of this index is 20.4 minutes for Norway, and 14.4 minutes for Spain. The closest airports in these countries are not always employed as origin airports; on average, people living in these countries who require better connectivity will spend this much extra time travelling to reach farther airports. On the other hand, Finland has an index of 5.6 minutes while France has an index of merely 0.4 minutes. In these countries, the airports closest to remote regions are better equipped to serve their population. 
Table 5. Statistics on land-side accessibility for remote territories (travel times in minutes).

\begin{tabular}{|c|c|c|c|c|c|c|c|c|}
\hline & Population & $\begin{array}{l}\text { No. of } \\
\text { Territ. }\end{array}$ & $\begin{array}{l}\text { No. of oric } \\
\text { airports }\end{array}$ & $\begin{array}{l}\text { Concentr. } \\
\text { by origin } \\
\text { airports } \\
\text { - HHI }\end{array}$ & $\begin{array}{l}\text { \% pop. } \\
\text { to closest } \\
\text { airport }\end{array}$ & $\begin{array}{l}\text { Travel tir } \\
\text { to the } \\
\text { closest } \\
\text { airport }\end{array}$ & $\begin{array}{l}\text { eTravel } \\
\text { time to } \\
\text { other } \\
\text { airports }\end{array}$ & $\begin{array}{l}\text { Connectivit } \\
\text { deficit of } \\
\text { the closest } \\
\text { airport } \\
\left(C_{d}\right)\end{array}$ \\
\hline Denmark & 1,993 & 1 & 2.0 & 8,080 & $89.2 \%$ & 124 & 201 & 8.3 \\
\hline England & 2,275 & 1 & 3.0 & 8,824 & $0.0 \%$ & 193 & 237 & 43.5 \\
\hline Finland & $1,602,466$ & 222 & 2.7 & 7,992 & $78.0 \%$ & 74 & 99 & 5.6 \\
\hline France & $1,857,975$ & 2,145 & 1.9 & 8,217 & $84.8 \%$ & 133 & 136 & 0.4 \\
\hline Germany & 60,890 & 41 & 4.0 & 7,497 & $16.9 \%$ & 119 & 319 & 166.2 \\
\hline Ireland & 82,558 & 7 & 3.0 & 6,675 & $79.6 \%$ & 109 & 191 & 16.8 \\
\hline Italy & 122,309 & 49 & 3.9 & 4,667 & $40.6 \%$ & 138 & 178 & 23.7 \\
\hline Norway & 584,225 & 288 & 2.0 & 8,104 & $75.0 \%$ & 63 & 145 & 20.4 \\
\hline Portugal & 66,058 & 6 & 2.6 & 7,713 & $52.3 \%$ & 201 & 227 & 12.7 \\
\hline Scotland & 44,300 & 13 & 2.8 & 9,905 & $76.7 \%$ & 77 & 85 & 1.9 \\
\hline Slovenia & 9,334 & 1 & 1.0 & 10,000 & $100.0 \%$ & 163 & - & - \\
\hline Spain & 781,126 & 414 & 2.6 & 7,208 & $62.8 \%$ & 105 & 144 & 14.4 \\
\hline Sweden & $1,133,261$ & 628 & 2.1 & 8,563 & $81.0 \%$ & 44 & 101 & 10.9 \\
\hline Wales & 4,515 & 1 & 2.0 & 5,790 & $30.1 \%$ & 196 & 213 & 11.9 \\
\hline All territor & ri6,353,285 & 3,817 & 2.2 & 8,021 & $79.6 \%$ & 114 & 141 & 6.9 \\
\hline
\end{tabular}

\subsection{Policy Implications}

The connectivity deficit index allows us to distinguish between the possible causes of remoteness. Based on this index and the percentage of total travel time spent reaching the origin airport, the following framework can point to the appropriate policy remedy.

- If the percentage of travel time to reach the origin airport is above average (see Table 4), the priority is to reduce land-side travel time.

- If the connectivity deficit in the remote territories is below average (see Table 5), it means that the airports are already well suited to serve the remote territories. To improve accessibility, the best policy is to improve roads and create new highways serving the airports. This is the case of France. 
- If the connectivity deficit in the remote territories is above average (see Table 5), the remote population is spending time traveling to airports that are farther away but have better connectivity. The priority of policy-makers should be to improve the closest airports' network quality. That could be obtained either by increasing the number of destinations or by increasing frequencies to major airports, when already connected. The population will then choose the closest airport more often, and spend less time traveling by ground. If the air service of the closest airports cannot be improved, the best policy is to improve land-side accessibility to larger but more distant airports. This is the case of Italy, Spain, and Portugal. It also applies to Germany, even though this country has a much lower population in remote territories.

- If the percentage of travel time by air is above average for remote territories (see Table 4), the priority is to reduce air-side travel time.

- If the airports closest to remote territories have a below-average connectivity deficit (see Table 5), it means they are already well placed to serve the remote population. The optimal policy is to increase the number of flights and destinations offered by the closest airports. If that is not possible, the government should improve both land- and air-side connectivity to larger airports farther away. This is the case of Finland.

- If the airports closest to remote territories have an above-average connectivity deficit (see Table 5), it means that some of the population employ more distant airports. The priority should be to increase the number of flights and destinations from those airports. An alternative policy is to improve the land-side accessibility to larger airports, with a more extensive network of destinations, further away from remote regions. The risk of this policy is to excessively increase access time by ground. This is the case of Sweden.

\section{CONCLUSION}

To the best of our knowledge, this work is the first to address the issue of accessibility in Western Europe at the municipality level. Our measure of accessibility is based all the overall travel times required to connect each pair of cities in the network, including ground travel to and from airports and waiting times between connecting flights when a direct flight is not available.

The paper defines remote territories as municipalities whose average travel time to other cities is above the 95th percentile. Norway, France, Finland and Sweden suffer most from remoteness.

We also propose a general framework to evaluate the best policy options at a Country level for alleviating travel times from remote territories. We determine whether improving land-side infrastructure or increasing the number of routes offered by airports will have the greater impact on accessibility. 
Specific analyses are still required to better identify the practical policies for particular territories. Another future development could be to carry out cost-benefit analyses of the different options identified to improve accessibility of remote regions.

\section{ACKNOWLEDGEMENTS}

We thank the participants of the 2011 ATRS conference in Sydney for their useful comments and suggestions on an earlier version of this paper. Any errors are our own. 


\section{REFERENCES}

- Burghouwt, G., Veldhuis J., 2006. The competitive position of hub airports in the Transatlantic market. Journal of Air Transportation 11(1), 1071-30.

- Chatelus, G., Ulied, A., 1995. Union Territorial Strategies linked to the Transeuropean Transportation Networks, Final Report to DG VII, INRETS-DEST/MCRIT, Paris/Barcelona.

- Copus, A., Spiekermann, K., Wegener, M., 2002. Aspatial peripherality?. Journal of NordRegio 3, 13-18.

- Lutter, H., Pütz, T., Spangenberg, M., 1992. Accessibility and Peripherality of Community Regions: The Role of Road, Long-Distance Railways and Airport Networks. Report to the European Commission, DG XVI, Bundesforschungsanstalt für Landeskunde und Raumordnung, Bonn.

- Malighetti, P., Paleari, S., Redondi, R., 2008. Connectivity of the European airport network: "self-help hubbing" and business implications. Journal of Air Transport Management 14, 53-65.

- Paleari, S., Redondi, R., Malighetti, P., 2010. A comparative study of airport connectivity in China, Europe and US: which network provides the best service to passengers?. Transportation Research Part E - Logistics and Transportation 46(2), 198-210.

- Redondi, R., Malighetti, P., Paleari, S., 2010. New routes and airport connectivity. Networks and Spatial Economics 11(4), 713-725.

- Shaw, S.-L., 1993. Hub structures of major US passenger airlines. Journal of Transport Geography 1(1), 47-58.

- Shaw, S.-L., Ivy R.J., 1994. Airline mergers and their effects on network structure. Journal of Transport Geography 2(4), 234-246.

- Spiekermann, K., Wegener M., 2006. Accessibility and Spatial Development in Europe. Scienze Regionali 5, 15-46.

- Vickerman, R., Spiekermann, K., Wgener, M., 1999. Accessibility and economic development in Europe. Regional Studies 33, 1-15.

- Wegener, M., Eskelinen, H., Fürst, F., Schürmann, C., Spiekermann, K., 2001. Criteria for the Spatial Differentiation of the EU Territory: Geographical Position. Study Programme on European Spatial Planning, Forschungen 102.2. Federal Office for Building and Regional Planning, Bonn. 


\section{INDUSTRY PERSPECTIVE: PREPARING AIRPORTS AND AIRLINES FOR TERRORIST ATTACKS}

Dr. William B. Rankin, II, AAE is an Associate Professor of Aviation Management at Florida Institute of Technology in Melbourne, Florida. Prior to this he was a Professor of Aviation Management and Chair of the Department of Aviation at the University of Central Missouri for 7 years, before stepping down in August of 2012. He was Deputy Director of Aviation for the Fort Lauderdale Hollywood International Airport overseeing the operations, maintenance, and planning and development sections of the airport. He has 29 years of airport management experience including the Director of Aviation for the El Paso International Airport, Texas; Manager of the Operations Division, Washington National Airport, Washington, DC; Director of the Eastern Iowa Regional Airport, Cedar Rapids, Iowa; and Manager of Smith-Reynolds Airport, Winston-Salem, NC. In addition, $\mathrm{He}$ is an Accredited Airport Executive in the American Association of Airport Executives: Email address: wrankin@fit.edu

Note: These views are not espoused by Florida Institute of Technology, but solely that of the author.

\section{INTRODUCTION}

With terrorist threats in the news, now may be the time for airports and airlines worldwide to review their security plans, and consider adoption a Security Management System (SeMS) for risk mitigation. Additionally, developing a checklist for employee training to protect employees from terrorist attacks should be encouraged. Many terrorist incidents may include, but not be limited to chemical, biological, cyber, radiation, nuclear blast, and explosives, that are likely threats to airports and airlines. For this very reason, every airport and airline should have already developed a security program that addresses terrorist threats. If your airport or airline does not have such a plan, volunteer you should develop one (Melton, 2003).

Evidence of terrorist threats is highlighted by three recent articles. An article published by the National Terror Alert Center of Homeland Security states that in the Middle East, "Terrorist groups have seized control of nuclear material at the sites that came out of the control of the state," and that such materials "can be used in manufacturing weapons of mass destruction" (The National Terror Alert Response System , 2014a). Another article published by Press TV states that the Khorasan Group has been, "carrying out research and experiments on improvised explosive devices created to undercut security at airports" (Press TV, 4014). Finally, an recent article on imminent 
attacks on the United States (U.S) claims that "agents across a number of Homeland Security, Justice and Defense agencies have all been placed on alert and instructed to aggressively work all possible leads and sources concerning this imminent terrorist threat" (The National Terror Alert Response System , 2014b).

\section{THE GOAL OF TERRORIST CELLS}

The goal of terrorist cells is to effect large-scale political or ideological change; however, their immediate goals are designed to achieve short-term goals attached to their actions. For this reason, the aviation security programs should ensure that employees know the various types of terrorist intentions and characteristics they might include (Melton, 2003). Popular literature on this subject suggests that terrorist intentions aim to:

1. To produce widespread fear.

2. To obtain worldwide, national, or local recognition for their cause by attracting the attention of the media.

3. To harness, weaken, or embarrass government security forces so that the government overreacts or appears repressive.

4. To steal or extort money and equipment, especially weapons and ammunition.

5. To destroy facilities or disrupt lines of communication in order to create doubt that the government can provide for and protect its citizens.

6. To discourage foreign investments, tourism, or assistance programs that can affect the target country's economy and support of the government in power.

7. To influence government decisions, legislation, or other critical decisions.

8. To free prisoners, and to

9. To satisfy vengeance. (Melton, 2003) 


\section{THE SECURITY MANAGEMENT SYSTEM}

To prepare for terrorist incidents, airports and airlines of all sizes need to consider the availability and response of local authorities in the event of a terrorist incident. Terrorist incidents may include large numbers of people, thereby making response by local authorities low or nonexistent. One problem with security programs, however, is that information in these programs may be highly restricted and not available to local security agencies and individual employees.

The answer to these questions may lie in the adoption of a Security Management System (SeMS). Just like Safety Management Systems (SMS), SeSM has four primary components: (a) policy, (b) risk management, (c), assurance, and (d) compliance. SeMS can be used to seek out and discover aviation security problems, such as non-compliant Security Identification Display Area (SIDA) challenge issues, or a construction employee's lack security compliance on the job site. In fact, a healthy SeMS can assist in the reduction of letters of investigation, and more importantly, security threats to passengers, airlines, and airport operations. A key component to the success of the SeMS relies on the concept of the accountable executive. This is the local official who is ultimately held responsible for meeting security compliance. At many airports or airlines this may be the local Security Coordinator, the Airport Director, or in the case of an airline, the Station Manager (Forrest and Price2013).

\section{SURVEY OF SELECTED U.S. AIRPORTS}

In a recent survey U.S. airports were surveyed. One hundred percent (100\%) of the respondents surveyed indicated that their security plans addressed the availability and response from local authorities, and $69.5 \%$ of the respondents indicated that their security plans addressed security incidents in all the categories of possible security threats. However, all other responses averaged less than $50 \%$ preparedness's in each case, with only $4.4 \%$ of the respondents indicating that they had a Security Management System (SeSM). Only 30.4\% of the respondents surveyed indicated that they provided employee training to all employees to prepare for terrorist threats/attacks/incidents. The sum of all the responses averaged only $38.15 \%$ preparedness overall.

Nine of the respondents to the survey answered a limited qualitative question on security preparedness's. These limited qualitative responses indicated that 6 respondents had employee training for chemical incidents; 5 for biological incidents: 1 for cyber incidents; 1 for radiological incidents; 3 for nuclear blast incidents; and 9 for explosive incidents; an average employee training preparedness of $18.2 \%$ for the responding airports. 


\section{CONCLUDING REMARKS}

In the wake of recent terrorist events, airports and airlines must prepare for terrorist attacks or incidents, and a recent survey of U.S. airports found a low level of security preparedness in the event of an actual attack. To correct these issues, now is the time for airports and airlines to review their security programs and prepare in the event of an actual terrorist attack or incident. This preparation should include the recognition of terrorist intentions and characteristics in today's world, types of potential attacks or incidents, recognizing terrorist activity, and incorporating heightened anti-terrorism awareness measures into security planning efforts. While the ideas set forth in this opinion may only be applicable in a small number of potential cases, the now is the time for airports and airlines to adopt a SeMS for security threat, or risk assessment. This would require that airports and airlines review their security programs, and consider the incorporation of a SeMS, which may be used for a number of emergency preparedness purposes, not just terrorist attacks or incidents. 


\section{REFERENCES}

- Forrest, J.S. \& Price, J.C. (2013). Airport operations, security, and maintenance. Alexandria, VA: American Association of Airport Executives.

- Melton, K. (2003). The U.S. Government Guide to surviving terrorism. New York: Barnes and Noble Books.

- Press TV (2014), US: Khorasan Group threat to aviation, para. 2. Available from: http://www.presstv.ir/detail/2014/09/27/380171/us-khorasan-group-threat-to-aviation/

- The National Terror Alert Response System (2014a). ISIS seizes 88 pounds of uranium from Mosul University - Report, para. 3. Retrieved August 29, 2014. Available from: http://www.nationalterroralert.com

- The National Terror Alert Response System (2014b). Imminent terrorist attack warning update: Ft. Bliss increases security, para. 1. Retrieved August 29, 2014. Available from: http://www.nationalterroralert.com 